4 Parker MJ, Gillespie LD, Gillespie WJ. Hip protectors for preventing hip fractures in the elderly. Cochrane Database Syst Rev 2000;(2): hip fractures

5 Kannus P, Parkkari J, Niemi S, Pasanen M, Palvanen M, Jarvinen M, et al. Prevention of hip fracture in elderly people with use of a hip protector N Engl J Med 2000;343:1506-13.

6 Van Schoor NM, de Bruyne MC, van der RN, Lommerse E, van Tulder MW, Bouter LM, et al. Cost-effectiveness of hip protectors in frail institutionalized elderly. Osteoporos Int 2004;15:964-9.

7 Parker MJ, Gillespie WJ, Gillespie LD. Hip protectors for preventing hip fractures in older people. Cochrane Database Syst Rev 2005;(3): CD001255.
8 Sawka AM, Boulos P, Beattie K, Thabane L, Papaioannou A, Gafni A, et al. Do hip protectors decrease the risk of hip fracture in institutional and community-dwelling elderly? A systematic review and meta-analysis of community-dwelling elderly? A systematic review and meta-

9 Parker MJ, Gillespie WJ, Gillespie LD. Effectiveness protectors for preventing hip fractures in elderly people: systematic review. BMJ 2006;332:571-3. 10 Van Schoor NM, Smit JH, Twisk JW, Bouter LM, Lips P. Prevention of hip fractures by external hip protectors: a randomized controlled trial. JAMA 2003;289:1957-62.

11 Van Schoor NM, Deville WL, Bouter LM, Lips P. Acceptance and compliance with external hip protectors: a systematic review of the literature. Osteoporos Int 2002;13:917-24.

\title{
Guantanamo: a call for action
}

\section{Doctors and their professional bodies can do more than they think}

A ccording to the British prime minister, Tony Blair, the detention facility at Guantanamo Bay, Cuba, is an "anomaly." Set against the Western tradition of ethics and human rights, the facility most certainly is, but it is also a place where detainees have lost all legal protection, torture is rife, and doctors have abandoned their ethical responsibilities.

The psychiatrist Robert Lifton, in studying the history and psychology of the Nazi doctors, showed how easily ethical principles were lost and replaced by acts that classified Jews, Romany gypsies, disabled people, and homosexuals as fit for the gas chamber and the medical laboratory. ${ }^{1}$ Such behaviour by doctors has been repeated (in different contexts) in the former Soviet Union, South Africa, and Chile, and now in Guantanamo Bay.

The cultural context in Guantanamo Bay was set by two US presidential decrees. The first was to remove the protection of the Geneva Convention from "combatants" suspected to be members of Al Qaeda and the Taliban. ${ }^{2}$ The second was to upwardly regrade torture, defining it as such only when the physical pain inflicted was "of an intensity that accompanies serious physical injury such as death or organ failure." Mental torture could only be so described if it produced "lasting psychological harm."

Doctors at Guantanamo Bay have been implicated in failing to report psychological and physical abuse of detainees, being present while torture takes place, and sharing detainees' medical records with interrogators. ${ }^{45}$ In addition, psychiatrists and psychologists have trained interrogators in techniques designed to inflict damage to mental health. ${ }^{6}$ The American Psychological Association has gone so far as to offer assistance in refining such methods. ${ }^{7}$ And now the long term hunger strike at Guantanamo Bay has been broken by force feeding, in which physicians are alleged to be willingly complicit. ${ }^{8}$

Towards the end of 2005 Senator John McCain, himself a survivor of torture, piloted legislation through the US Senate requiring detainees, wherever held, to be treated humanely. ${ }^{9}$ This principle is now enshrined in the Detainee Treatment Act 2005, the provisions of which are currently being used as the basis for an action in a US Federal Court by lawyers acting on behalf of four hunger strikers at Guantanamo Bay. The case centres on whether the force feeding of detainees amounts to torture, not only in the context that feeding is in conflict with a consistent and competent refusal, but that the forcible methods used also amount to torture. ${ }^{10}$
Last month, four of the United Nations' special rapporteurs, reporting to the UN Commission on Human Rights, declared that interrogations authorised by the US Department of Defense and force feeding "amounted to torture" as defined in article 1 of the Convention against Torture. ${ }^{11}$ The US government allowed the rapporteurs to visit Guantanamo Bay but refused them any contact with detainees: thus the UN report depended, in the main, on interviews with lawyers and former detainees.

Until recently, international codes of ethicsparticularly the World Medical Association's (WMA) codes of Tokyo and Geneva-have been thought sufficient to protect patients and to inhibit doctors from taking part in this kind of abuse. Events at Guantanamo Bay show that this is no longer the case, primarily because of the legal vacuum in which detainees are held there.

In relation to force feeding, the WMA's Declaration of Malta (1991) ${ }^{12}$ is wholly inadequate. In 2001, after long hunger strikes in Turkish prisons caused many deaths, the BMA identified discrepancies between the two relevant WMA declarations. Whereas the Tokyo declaration-in line with general ethical rules-advises against involuntary artificial feeding of protesters who have competently refused nutrition (even if this leads to their death), ${ }^{13}$ the Malta declaration allows doctors to decide on the appropriateness of resuscitation and artificial feeding. Support for this discretion is based on the view that it is essential to look beyond what initially seems to be an autonomous decision to go on hunger strike, and to consider the possibility of peer pressure.

In an attempt to resolve these contradictions, in 2001 the BMA offered a revised draft of the Malta declaration, which requires doctors to respect an informed refusal of feeding unless the refusal was coerced. The WMA refused to alter the declaration. In the light of events at Guantanamo Bay, the BMA has submitted a completely new version of the Malta declaration for the WMA meeting in May 2006, in an attempt to make it both relevant and effective. But, even if the WMA adopts this new declaration, this will have limited effect unless national medical associations are willing to make their members accountable when practice departs from principles.

The individual doctor-patient relationship is founded on the principles of autonomy, beneficence, and justice. That these principles apply on a wider national and international scale, and that they are articulated by a caring profession, gives doctors enormous power. That they can successfully challenge
See also News p 569 
authorities demanding their collusion in unethical behaviour is illustrated by the recent successful, possibly permanent, suspension of capital punishment in California after a refusal by doctors to administer lethal injections. ${ }^{14}$

Lifton has shown the ease with which doctors can drop their ethical guard, in ways that do not have to be as stark as the horrors of Guantanamo Bay. ${ }^{1}$ National and international medical bodies need to understand that not only do they have more power than they generally assume, or choose to use, but that to use that power is a basic ethical duty. This duty is as basic as the application of ethical principles in the daily life of a practising doctor.

Michael Wilks chairman, Medical Ethics Committee

(mwilks@bma.org.uk)

British Medical Association, London WC1H 9JP

Competing interests: None declared.

1 Lifton R. The Nazi doctors: the psychology of medical killing. London: Papermac, 1986.
2 Humane Treatment of al Qaeda and Taliban detainees. Memo from the President. 7 Feb 2002. Washington. www.washingtonpost.com/wp-srv/ nation/documents/020702bush.pdf (accessed 6 Mar 2006)

3 Standards of Conduct for Interrogation under Sections 2340-2340A of title 18 of the United States Code. Memorandum for Alberto R Gonzales, Counsel to the President. 1 Aug 2002; US Department of Justice. Washington. www.washingtonpost.com/wp-srv/nation/documents/ dojinterrogationmemo20020801.pdf (accessed 6 Mar 2006).

Bloche M, Marks J. Doctors and interrogators at Guantanamo Bay. NEngl JMed 2005;353:6-8

Lifton R. Doctors and torture. N Engl J Med 2004:351:415-6.

6 Physicians for Human Rights. Break them down-systematic use of psychological torture by US Forces. Boston, MA: PHR, 2005. www.phrusa.org/ cal torture by US Forces. Boston, MA: PHR, 2005. Www.phr
research/torture/pdf/psych_torture.pdf (accessed 6 Mar 2006).

$7 \begin{aligned} & \text { research/torture/pdf/psych_torture.pdf (accessed 6 Mar 2006). } \\ & \text { Report on the American Psychological Association Presidential Task Force on }\end{aligned}$ Report on the American Psychological Association Presidential Task Force on
Psychological Ethics and National Security. 2005. www.apa.org/releases PENSTaskForceReportFinal.pdf (accessed 6 Mar 2006).

8 District Court of British Columbia: case 1:05-cv-00520-RMU; doc.58-3, Declaration of John S Edmondson MD, filed 30 Sep 2005.

9 Analysis: US torture ban law. 2005. http://news.bbc.co.uk/1/hi/world americas/4533612.stm (accessed 6 Mar 2006).

10 US cites exception in torture ban. Washington Post 2006;Mar 3:section A:4

11 United Nations Commission on Human Rights. Situation of detainees at Guantanamo Bay. Geneva: UN Economic and Social Council, 2006. (E/CN.4/2006/120.)

12 World Medical Association. Declaration of Malta. Geneva: WMA, 1991

3 World Medical Association. Declaration of Tokyo. WMA, 1975. (Revised 2005.) www.wma.net/e/policy/c18.htm (accessed 6 Mar 2006).

14 Doctors halt "painless" execution. http://news.bbc.co.uk/1/hi/world/ americas/4734908.stm (accessed 6 Mar 2006).

\title{
Inverse association between appendicectomy and ulcerative colitis
}

\author{
It's too early to recommend prophylactic appendicectomy
}

A

$\mathrm{n}$ inverse association between appendicectomy and risk of ulcerative colitis was first reported in 1987 as an unexpected finding in a study of childhood determinants of inflammatory bowel diseases. ${ }^{1}$ The major impetus, however, for the current interest in the association was a 1994 case-control study which reported that only $0.6 \%$ of patients with ulcerative colitis had had their appendix removed before diagnosis, compared with $25.4 \%$ of controls from orthopaedic clinics. The corresponding odds ratio of 0.02 launched the idea that appendicectomy protects against ulcerative colitis. ${ }^{2}$ But is this so?

Subsequent case-control studies have confirmed the inverse association, although with considerably less extreme odds ratios. In 2001, however, review of the available literature showed that most studies had used inappropriate or questionable methods, ${ }^{3}$ and the number of unclear or overtly flawed case-control studies has increased since then. One common problem is the failure to use identical methods and periods for the ascertainment of previous appendicectomies in the patients with ulcerative colitis and in the controls. In several studies, unconditional logistic regression analysis was used in situations where the individual matching should have been retained to avoid over-ascertainment of appendicectomies among controls. Other common problems include the lack of adjustment for confounding factors known to be linked both to appendicectomy and ulcerative colitis risk (such as tobacco smoking) and the use in most studies of hospital controls, who will differ considerably from the background population on many health and lifestyle issues.

Among the more than 25 published studies, only a few research teams who described their methods in succeeded in applying a sound study design and appropriate analysis strategy to reasonably valid and complete data sources. Two such teams, who focused on appendicectomies in childhood and adolescence, reported significant odds ratios of 0.06 for ulcerative colitis with onset before the age of 17 years $^{4}$ and 0.05 for ulcerative colitis with onset between 16 and 45 years of age. ${ }^{5}$ Other studies considering appendicectomies in a broader age range reported more moderate but still significant odds ratios of $0.3-0.4 .^{6-8}$

Thus far, there have been only two national cohort studies on the subject. Swedish researchers followed 212963 people who had had their appendix removed and a control cohort of equal size matched for sex, age, and place of residence. Overall, the incidence of ulcerative colitis was $26 \%$ lower in the appendicectomy cohort (relative risk $0.74,95 \%$ confidence interval 0.64 to 0.86 ), an association that was largely due to $58 \%$ lower rates of ulcerative colitis among people who had had an appendicectomy for confirmed appendicitis before the age of 20 (relative risk $0.42,0.31$ to 0.57 ). In contrast, no subsequent reduction in ulcerative colitis incidence was found for appendicectomies for appendicitis after age 20 (relative risk $0.97,0.79$ to 1.18 ) or for non-specific abdominal pain $(1.06,0.74$ to 1.52$) .^{9}$ In Denmark, the overall incidence of ulcerative colitis among 154434 people who had had an appendicectomy was 13\% lower than expected based on ulcerative colitis rates in the general population (relative risk $0.87,0.69$ to 1.07 ). As in the Swedish study, relative risk estimates were lower for people aged $<20$ years at appendicectomy and for those who had had a perforated appendicitis, although these associations did not reach significance. ${ }^{3}$

If we disregard studies with poor or inadequately described methods, the evidence still supports an 